\title{
Political Economy of Land Use in Indonesia: Trap and Curse of Natural Forests
}

\author{
Sudarsono Soedomo
}

\begin{abstract}
Department of Forest Management, Faculty of Forestry and Environment, IPB University, Academic Ring Road Campus IPB
\end{abstract} Dramaga, Bogor, Indonesia 16680

Received February 15, 2021/Accepted December 30, 2021

\begin{abstract}
The allocation of land use in Indonesia is very inefficient, while the distribution of tenure is unequal. Half of the land for cultivation is held by forestry, and the other half is used by various other sectors. Most Indonesian farmers are small-scale farmers who do not meet economies of scale. Agrarian reforms aimed at overcoming inefficiency in land use, eliminating inequality in land tenure, and promoting rural areas' prosperity need to involve land for cultivation allocated for forestry. This paper is written based on the author's experience of interacting with various parties related to land issues, forest areas and agrarian reform through various forums, such as official meetings, focus group discussions, seminars, workshops, symposiums, one-on-one discussions (interviews), and interactions through social media. Agrarian reform, which has been launched since 1960, has not been able to be realized until today. The fight seems to involve two large groups, namely environmentalists and developmentalists, but this kind of grouping is likely to be misleading. Environmental issues may only be used as an instrument to obtain economic benefits as well, not for the environment itself.
\end{abstract}

Keywords: legality, uncertainty, efficiency, equity, prosperity, sustainability, abuse of power

*Correspondence author, email: ssoedomo@apps.ipb.ac.id

\section{Introduction}

The clear land status is fundamental and crucial for economic development in general and agriculture development in particular. However, this is what has been missing in Indonesia until very recently. Bedner (2016) provides a comprehensive 'big picture' history of Indonesian land law nicely in the post-colonial era. He further maintains that the core of the problem with land law in Indonesia is how the institutions responsible for the operation of the rules open the door to evasion and abuse. Besides, no judiciary is able to remove the legal uncertainties surrounding land law. Instead, the judiciary often worsens the situation. In essence, Indonesia's land problem is that land tenure of millions of Indonesians is insecure.

Land law uncertainties due to the duality of land law, the basic agrarian law and forestry law, have been recognized. However, how the forestry law has been used to merely exercise power rather than to prosper the people is never addressed. According to Campbell in Lucas and Warren (2013), the forestry authority has the power to reverse land reform through the forestry law. In addition, based on the size of land controlled, Fox et al. (2009) categorize forestry authority in Indonesia, Ministry of Environment and Forestry, as one of the most powerful ministries. Today, the minister controls more or less $65 \%$ of 128 million ha of Indonesia's land. Sadly, the contribution of the forestry sector to the national gross domestic product (GDP) has been less than $1.0 \%$ (Table 1). This indicates that most of the land controlled by forestry authorities is idle or unproductive. In addition, out of the 11.8 million ha of land that has received permits for industrial plantation forest development, only around 4.0 million ha have been developed. It also shows that investment in industrial tree plantations is not attractive.

Land use in Indonesia is unequal and inefficient. About two-thirds of the land is claimed as forest area, while the other third is for various needs spatially classified as cultivation areas. However, in terms of contribution to GDP, the forestry sector's contribution is only less than $1.0 \%$. In other words, most of the land in Indonesia is not used productively or is even left idle unproductively. As a country whose main diet is rice, Indonesia only has about 7.4 million ha of irrigated rice fields, while allocating 60 million ha for production forests which are generally highly unproductive. With rice fields and the level of productivity of Indonesian farmers in general, the quantity of rice produced is approximately the same as current consumption needs. In fact, from the paddy fields also corn, soybeans, and sugar cane are produced. Therefore, it is not surprising that for some food products, Indonesia has been heavily dependent on imports. The most striking reactions from audiences, including academicians and government officials, whom I have presented those figures, are not aware of the situation.

Indonesian agriculture is very fragile and does not provide the welfare for most of its farmers. Indonesian agriculture is characterized by a very large number of farmers but with a very small scale of business. Until 2020 there are around 37 million people, coming from 28 million households, working in the agricultural sector. As a country with a large population, Indonesia has a relatively small per capita area of land for food crops, which is only $1,900 \mathrm{~m}^{2}$ (Table 2). In a state of emergency, getting food in large quantities from international markets will be very difficult, 
Table 1 Contribution of agriculture-related sectors to gross domestice product (GDP, billion IDR)

\begin{tabular}{|c|c|c|c|c|c|c|c|c|c|c|}
\hline & \multicolumn{2}{|c|}{2010} & \multicolumn{2}{|c|}{2015} & \multicolumn{2}{|c|}{2016} & \multicolumn{2}{|c|}{2017} & \multicolumn{2}{|c|}{2018} \\
\hline Food crops & $151,500.7$ & 6.56 & $280,018.8$ & 3.12 & $287,216.5$ & 3.04 & $293,858.0$ & 2.96 & $298,146.1$ & 2.86 \\
\hline Estate crops & $47,150.6$ & 2.04 & $345,164.9$ & 3.84 & $357,147.7$ & 3.79 & $373,194.2$ & 3.76 & $387,496.7$ & 3.72 \\
\hline Livestocks & $38,214.4$ & 1.65 & $136,936.4$ & 1.52 & $143,036.5$ & 1.52 & $148,688.8$ & 1.50 & $155,539.9$ & 1.49 \\
\hline Forestry & $17,249.6$ & 0.75 & $60,623.5$ & 0.67 & $60,002.0$ & 0.64 & $61,279.6$ & 0.62 & $62,981.8$ & 0.60 \\
\hline Fishery & $50,661.8$ & 2.19 & $204,016.8$ & 2.27 & $214,596.6$ & 2.27 & $226,833.2$ & 2.29 & $238,616.2$ & 2.29 \\
\hline GDP & $2,310,689.8$ & 100.00 & $8,982,517.1$ & 100.00 & $9,434,613.4$ & 100.00 & $9,912,928.1$ & 100.00 & $10,425,397.3$ & 100.00 \\
\hline
\end{tabular}

Table 2 Cropland in several countries

\begin{tabular}{lc}
\hline Country & Cropland $\left(\mathrm{m}^{2}\right)$ \\
\hline Australia & 12,640 \\
Brazil & 3,049 \\
Canada & 10,441 \\
India & 1,266 \\
Indonesia & 1,938 \\
Myanmar & 2,355 \\
Thailand & 3,079 \\
US & 4,935 \\
Vietnam & 1,218 \\
\hline
\end{tabular}

with the potential to cause political instability and in turn, social chaos. In addition, the level of inequality in land tenure reached 0.60. Smallholders are generally seasonal crop producers, especially food crops. Meanwhile, farmers with large land areas generally work on plantations. Therefore, it is not surprising that Indonesia becomes an importer of foodstuffs, particularly rice, corn, soybeans and sugar because the land allocated for food crops is indeed insufficient.

The purpose of this paper is to show how substantial agrarian reform is impossible without dismantling the power that grips land claimed as forest areas. Natural forests have become a trap and a curse for nation-building after previously being considered a blessing. It is not actually the natural forest itself that is bad but the illusionary mindset, which was formed by natural forests that were once abundant in the past, is the source of the problem. Although many parties have realized and acknowledged that there are fundamental problems in land allocation in Indonesia, the problem of misallocation is still difficult to discuss openly, especially among government officials. Forest areas seem to be sacred objects that should not be touched. The "ewuh-pakewuh" culture causes a problem not to be immediately raised and discussed openly to find a solution. ${ }^{1}$ Another objective of this paper is to desacralize this forest area, especially production forest areas. Ecologically, plantation production forest is no different from other annual crops, so there is nothing to be privileged about.

The approach This article is constructed on the basis of my experiences of repeatedly long term interactions with diverse stakeholders, including expert workshops, semi-structured interviews, focus group discussion, and discussions through social media addressing relevant issues. The participants in the interviews and focus group discussions were selected using non-probability sampling. This allows the researcher to choose specific key informants who can provide and explore particular needed and relevant information. This method was also used because the aim was not to achieve statistical generalization but rather to gain a deeper understanding of the social processes related to the study (Robson, 2002). All opinions, views, and information gathered from those interactions were synthesized to produce this paper. In essence, I was a participant-observer. Enrichment was done through literature studies and exploitation of relevant field visit findings that had been done previously. The group struggle model of policy making is employed to analyze the situation.

Dynamics of the agrarian reform According to the National Land Agency, the definition of agrarian reform is the process of restructuring the rearrangement of ownership, control and use of agrarian resources, especially land. In Article 2 of the Decree of the People's Consultative Assembly of the Republic of Indonesia Number IX/MPR/2001, it is explained that the agrarian reform includes a continuous process with respect to the rearrangement of land ownership, use and utilization of agrarian resources, implemented in the framework of achieving legal certainty and protection and justice and prosperity for all people of Indonesia.

The period of 1960-1967 In the global fora, this period is colored by the cold war, which divided the world into two blocks; the west was led by the USA and the east was led by the former USSR. Although President Soekarno had initiated non-block in 1955 by holding the Asia-Africa Conference in Bandung, over time he fell into the east block. Until 1965, the Indonesian Communism Party (PKI) was so influential. At that time, the Jakarta-Beijing axis was established as a symbol of the close relationship between Indonesia and China.

This period was marked by the enactment of Act 5 of 1960 regarding the Basic Agrarian Law (UUPA) and Act 56 of 1960 regarding the size of farmland. The acts were administered by the Minister of Agrarian (Feb 18, 1960March 2, 1962), the Minister of Agriculture and Agrarian (March 6, 1962-Nov 13, 1963), and the Minister of Agrarian (Nov 13, 1963-July 25, 1966). The quick-change reflects political turbulence at that time. Politicians were struggling for their position rather than serving the people.

Regarding land ownership, the Act 5 of 1960 states: 1) to prohibit excessive ownership of land (The article 7) and 2) to determine the maximum and minimum size of land ownership by a household or legal body (The article 17). 
Table 3 Population density classification

\begin{tabular}{ll}
\hline Population per $\mathrm{km}^{2}$ & Category \\
\hline$\leq 50$ & Not dense \\
$51-250$ & Less dense \\
$251-400$ & Quite dense \\
$>400$ & Very dense \\
\hline
\end{tabular}

Moreover, in the supplement of Act 56 of 1960, we can find that the categorization of population density as a basis of determining the maximum size of land ownership is carried out for each regency (Table 3 and Table 4). Although the act also mentions the transmigration as a tool of land reform, the regency based-categorization of population density is disadvantageous for densely populated regencies, such as the ones in Java Island in general. It seems that the agrarian reform tends to be biased towards the situation of Java Island, which has a very dense population compared to other islands.

The euphoria of the agrarian reform was so intent, especially in rural areas in Java and Bali. Strong supports came from the PKI and its affiliated mass organization such as the Barisan Tani Indonesia (BTI-peasants' organization). It made perfect sense because the PKI was a political party that was the loudest advocate of the issue of equity, which was packaged in the motto of 'sama rata sama rasa' (equality). The powerful support from the PKI then became a major obstacle to the agrarian reform movement for the decades since the PKI was declared a banned party until around the year of 2000. On the opposite side, the most formidable challenges were done by the religious organizations in Java, Lombok, and Sumbawa (Utrecht, 1969). The Indonesian economy was in deep trouble, marked by the inflation rate of $650 \%$.

The events of 1965 dramatically reversed the political fortunes of the forces supporting land reform. The massacres and mass arrests of the main advocates of land reformthe PKI and its affiliated organizations, in particular the peasant organization Barisan Tani Indonesia (BTI)and the dismantling of the land reform administration practically stalled the implementation of the program, although the land reform law itself was never formally repealed (Lucas, 1992). In early 1960, a regime change from the Old Order, civilian and led by President Soekarno, to the New Order, military and led by President Suharto.

The New Order Regime attempted to recover the economy by promoting investments. To support these efforts, the New Order Regime issued several acts, one of them is the Act 5 of 1967 regarding forestry basics. This act was the foundation for massive exploitation of natural forests in the outer Islands, mainly Sumatera, Kalimantan, and Sulawesi. Moreover, this act has played a role in destroying the traditional land utilization institutions, discouraging more efficient land utilization, and hampering the agrarian reform. As Utrecht (1969) suggested, the New Order Regime did not have the political and ideological interest in its predecessors' land reform of its predecessor. However, soon it will be clarified that it is not entirely true.

The period of 1967-1999: The sub-period of 1967-1983 The forest resources were so abundant, and most of Indonesia's lands have not been registered. The Act 5 of 1960 was
Table 4 Maximum land area

\begin{tabular}{lcc}
\hline \multirow{2}{*}{ Population density } & \multicolumn{2}{c}{ Maximum area } \\
\cline { 2 - 3 } & Wetland (ha) & Dryland (ha) \\
\hline Not dense & 15.0 & 20.0 \\
Less dense & 10.0 & 12.0 \\
Quite dense & 7.5 & 9.0 \\
Very dense & 5.0 & 6.0 \\
\hline
\end{tabular}

administered by the Directorate General of Agrarian under the Ministry of Home Affairs (July 25, 1966-March 17, 1993), while the Act 5 of 1967 was administered by the Directorate General of Forestry under the Ministry of Agriculture. The rivalry between the two authorities of Indonesia's lands has started. Publications on the land-related issues rarely mention the tension between UUPA and UUPK (Lucas, 1992). The most crucial element of Act 5 of 1967 is the definition of forest land (kawasan hutan). In article 1(4), forest areas were defined as "certain areas that had been assessed by the Minister to be maintained as 'permanent forest' (hutan tetap)." The 'permanent forest' was a keyword, but unfortunately, it was not defined in Act 5 of 1967. The definition of the permanent forest came so late in the Government Regulation 10 of 2010 article 1(12): 'Permanent forest' is a forest area that will be maintained as a forest area, consisting of conservation forest, protected forest, limited production forest, and permanent production forest. This silly circular logic shows that what matters is land instead of the forest.

Four steps that ought to be done for an area to be legally named forest area, which are a) designation, b) demarcation, c) mapping, and d) gazetting. These four steps together are called the establishment of forest area (pengukuhan kawasan hutan). The demarcation is complete if the boundary line meets end to end, and all rights of third parties are settled. Hence, the third parties whose lands are situated next to the area being demarcated must be involved in the process of demarcation. This is the hardest part of the establishment of forest area, and sadly there is no budget allocated to resolve the disputes. In short, those four steps have never been followed through, so that practically almost all areas claimed as forest areas are still in the step of designation. Furthermore, the cumbersome establishment processes have inspired the forestry community to create a shortcut. This is found in the definition of the new forestry act discussed later.

In the early 1970s, the New Order Regime introduced the Forest Utilization Right (HPH). The government, namely forestry authority, granted virgin forests to the private companies close to the center of the power. Behind the companies were usually high-rank military persons, who were active or retired already. While few people became so rich, the indigenous people were alienated and remained poor. They were the spectators of massive timber mining around their settlements. These indigenous people have been the most vulnerable players in future land games. Practically, many indigenous people lost their lands when the forestry authority claimed the lands as forest lands. Those indigenous people have not been able to protect their lands legally since they have not had any legal document as an evidence of the ownership. As a matter of fact, land registration has been quite limited in Indonesia (Haar, 1976). In addition, negative parlance used to be employed to describe their habits, such as 
shifting cultivation, forest encroachment etc. Certainly, what the government did, regarding the indigenous people and the land, was the violation of the UUPA.

Instead of using the term of agrarian reform explicitly, the New Order Regime used the term of transmigration program (Lucas, 1992; Lipton, 2009). This is exactly what Wolf Ladejinsky suggested in the 1960s (Walinsky, 1977). Through the transmigration program, the government redistributed the population from heavily populated islands, such Java and Bali, to less populated islands, such as Sumatera, Kalimantan, and Sulawesi. Each participating household was given 2.00 ha of land, a little house, and 18month stipend. Moreover, it indicates that it was not the agrarian or land reform agenda itself that was taboo for decades as suggested by McCarthy \& Robinson (2016), but merely the parlance of the agrarian reform.

There were two types of transmigration program, e.g. general transmigration and spontaneous transmigration (MacAndrews, 1978). Under general transmigration, the participants are fully supported from the time of dispatch from Java through the initial settlement period until the village is finally handed over to the local leader. Under spontaneous transmigration, however, the participants move entirely of their own accord but can settle on a government project on arrival. Currently, the migration of people from Java to other islands is generally on their own initiative with the help of relatives or friends who have settled in the new place.

The sub-period of 1983-1999 The most substantial events during this period were the rebirth of the Ministry of Forestry in 1983, introduction of the agreed forest land use (TGHK) map in 1986, the BPN was born in 1988, and the rebirth of the Ministry of Agrarian that was united with the BPN in 1993. Later, we will recognize how the TGHK have complicated the development of an optimal spatial plan along the way to the present days. In fact, the real competition is not in the forest resources but the land resources. This is evident from the resistance of the forestry authorities to prefer to leave the land idle rather than handing over to other sectors that need and are able to utilize the land more productively. Perhaps, this is driven by what is called loss aversion (Kahneman \& Tversky, 1984) or a status quo bias (Samuelson \& Zeckhauser, 1988).

During this sub-period, mainly the first five years, the forestry was in the strongest stage in the Indonesian land use political economy. The Minister of Forestry was assumed by a strong figure (Mr. Sudjarwo) who had a solid tie with the President. Meanwhile, the largest part of Indonesian forests were still abundant in timber. At that period, timbers from virgin forest meant quick cash. With the visible money, the voice of the forestry was powerful, so that economic justifications could nicely be employed to support the claim over the lands designated for forestry known as the TGHK. Whereas, in the same period, the Ministry of Agrarian/BPN spent a larger amount of money than it could collect. However, it seems that natural forests that were once abundant and helpful in a period have become a trap, if not a curse, for the Indonesian people's future journey.

The TGHK was developed for each province in the form of maps signed by representatives of each provincial office of sectors, mainly the land-based sectors. The maps' scale was too small, namely $1: 2,500,000$, indicating that the map was temporarily indicative. Moreover, five land uses are presented on the map: conservation forests, protection forests, limited production forests, regular production forests, and other land uses. Moreover, there were cases where almost the entire province was designated as forest areas, provinces of Riau and of Kalimantan Tengah. Shortly, we will encounter that the TGHK makes land-use change extremely costly and hampers economic development in general. Campbell (1999) in Lucas \& Warren (2013) considers the TGHK as reverse land reform - policy changes that facilitated land concentration in the hands of elite political-business interest that the UUPA explicitly describes as "harming the public interest."

The period of 1999-2019 This period was begun by the removal of the Ministry of Agrarian in 1999 but the Head of the BPN was hold by the Minister of Internal Affairs. The major mandate of the BPN was to execute the UUPA. At the same time, the Ministry of Forestry was maintained and the new forestry act, Act 41 of 1999, was enacted to replace the Act 5 of 1967. There has been a change in political power that is more favorable to forestry, although the signs of decreasing forestry's contribution to national development have been increasingly insignificant. This period, particularly between 2000 and 2002, was also marked by the massive extraction of wood from forests by the local community, which can be read as an expression of the community's dislike for the behavior of forestry officials so far.

Since the forest areas had been extremely difficult to establish under Act 5 of 1967, the definition of the forest areas was changed substantially in Act 41 of 1999. The forest areas are "certain areas that have been designated and or assessed by the Government to be maintained as 'permanent forest' (hutan tetap)." Whereas, the four steps required to establish forest areas are still maintained. In other words, the Act 41 of 1999 has tried to shortcut the establishment of forest areas, under which a designation by the government is enough to establish forest area. Please be noted carefully that the designation ought to be conducted by the government, not the minister having forestry authority. At this point, the abuse of power by the forestry authorities has been so frequently occurring. In this context, I fully accept what is conveyed by Bedner (2016): "The core of the problem with land law in Indonesia is not the complexity of its rules, but rather how the institutions responsible for the operation of the rules open the door to evasion and abuse. In particular, the bureaucratic competition within the state and the absence of a judiciary that is able to remove the legal uncertainties surrounding land law are problematic."

However, the power abuse at the national level has been challenged by local powers who have stronger direct control over the lands. The abusive national power is played by the Forestry Authority. The local powers, on the other side, are risk-loving investors backed up by individuals with strong political positions. The tension between the two might involve physical clashes when they meet on the ground. This 
situation is dangerous for forestry officials to patrol the lands. Hence, the forestry authority controls the land on the map, while its opponents control the land on the ground. The lands themselves are not necessarily covered by forests, instead mostly have been covered by bushes for years.

The designation of forest areas positively influences the spatial plan that involves the entire lands. Hence, it is quite logical if the spatial plan is developed by the government involving various authorities, not just merely forestry authority. Above all, the spatial plan was under the authority of the Minister of Public Work until October 2014, since that time it has been under the authority of the Minister of Agrarian and Spatial Plan/BPN. Moreover, the government meant in Act 41 of 1999 is the central government without further explanation. The definition of the central government is found for the first time in the Act 26 of 2007 regarding the spatial plan, which is the President of the Republic of Indonesia who assumes governmental power of the state of the Republic of Indonesia as meant in the constitution of the state of the Republic of Indonesia. Under such a clear definition, the Minister of Forestry often acts as if it is the government meant by Act 41 of 1999 , which is certainly an abuse of power. Strangely enough, power abuse has been rarely challenged.

On November 9, 2001, the Indonesian people through the People's Consultative Assembly (MPR) enacted the TAP MPR Number IX/2001 in which article 2 commissioned the Indonesian government to implement agrarian reform to achieve legal certainty, protection, justice and prosperity for all Indonesian people. ${ }^{2}$ Until today, this decree has not been realized. Moreover, the agrarian reform becomes harder and harder to execute when environmental issues have massively entered the equation of development. The agrarian reform has been facing a new challenge raised by groups of people whose livelihood is dependent on their voices regarding environmental issues, such as deforestation and biodiversity conservation. However, rather than preserving the forest, this approach may lead to the tragedy of desperation caused by what Henley (2008) call the 'desperate ecocide' of the poor. The definition of forest and forest area is intentionally obscured, so that the reduction of forest area is immediately misinterpreted as causing deforestation. In fact, many forest areas have not been forested for a long time. There is currently at least 35.5 million ha of production forest area that are not forested (Table 5). Thus, using this land for economic development will not lead to deforestation, due to the fact that deforestation has occurred long before.

\section{Discussion}

Several agrarian studies, including the Indonesian cases, have been conducted, but the focus mainly on redistributing the excessive lands controlled or owned by private entities (Utrecht, 1969; Tjondroegoro, 1972; Lipton, 2009). A private entity, commonly a private corporation, may control public lands given by the government in the form of a business use right (HGU), usually planted with perennial crops such as rubber, cacao, and oil palm. Surrounding the HGU is people with small lands or landless people working for the corporation managing the HGU. Over time the population of landless people surrounding the HGU becomes so large, so that the gap between the rich and the poor becomes wider. The gap strengthens the demand for the agrarian reform justifiably. This situation was already detected by Wolf Ladejinsky in the early 1960s and he maintained that the real issue in Java (and Bali) is not land redistribution but population redistribution on the one hand and a breakthrough in agricultural productivity on the other (Walinsky, 1977).

The UUPA basically looks at inequality in land tenure in the local context; farmers in areas that are already densely populated will also get small land. Land surpluses and deficits are examined per region. Therefore, if agrarian reform is implemented purely by the UUPA, inequality in land tenure between regions will still exist. The region meant here is a second level region. In fact, the explanation of Article 17 allows the government to distribute land outside Java through the transmigration program. It appears that UUPA is biased towards the situation in densely populated areas, such as Java and Bali.

If agrarian reform is carried out in Java and other densely populated islands, the impact on improving the distribution and efficiency of land use in Indonesia will be limited, while the social, economic and political costs will be high. Land reforms are expected to enhance land use efficiency and investment, reducing poverty and promote more sustainable land management that altogether stimulate economic growth (Holdena et al., 2013). In addition to the limited land area available, almost all land in Java has been managed by the private sector. Thus, the government ought to deal with the private sector who has controlled the land. In fact, the government itself has controlled an enormous land surplus in

Table 5 Land use in Indonesia

\begin{tabular}{lccc}
\hline Land use & Area (ha) & Proportion (\%) & Unforested(ha) \\
\hline Conservation forest & $22,108.8$ & 11.8 & $4,551.2$ \\
Protection forest & $29,661.3$ & 15.8 & $5,750.1$ \\
Limited production forest & $26,787.9$ & 14.3 & $5,522.0$ \\
Production forest & $29,220.3$ & 15.5 & $12,190.4$ \\
Convertible production forest & $12,822.8$ & 6.8 & $6,526.5$ \\
Other land use & $67,150.8$ & 35.8 & $59,261.9$ \\
\hline Total land & $187,752,000.0$ & 100.0 & $93,802.1$ \\
\hline
\end{tabular}

Source: Statistik KLHK (2017)

${ }^{2}$ TAP is a decree 
the form of an area that is claimed as a forest area. In short, if the agrarian reform or land reform is to solve the problem of inefficiency and equal distribution of land tenure as stated by Atkins (1988), then forest areas must be the first priority object of the agrarian reform.

Strangely, agrarian reform outside Java, which merely involves land that the government fully controls, has not worked as expected. The implementation of the Forestry Law, both Law 5/1967 and its successor to Law 41/1999, complicates the situation. Instead of distributing land to the people, the forestry authorities took people's land. The expropriation is not meant to confiscate the surplus land that is controlled by private individuals to be distributed to other individuals who are in deficit, but for the desire to control the land for sectoral interest. The resistance of the forestry authorities to agrarian reform is considerably strong; In various forestry community meetings, the term agrarian reform is strongly avoided. One of the clearest formal forms of resistance to agrarian reform is an introduction of policies on social forestry. Even the Vice President of the Republic of Indonesia and lately the President himself has spoken that there is a serious problem in the land policies and there are two conflicting views within the government itself. In October 2019 the President himself mentioned that the Perhutani ${ }^{3}$ has been acting more colonial than colonial itself, which is no longer relevant to current situations. The mention of Perhutani should be interpreted as a strong allusion to the behavior of the forestry authorities in general, but it seems that the forestry authorities have lost their social sensitivity. Secretly, the forestry authorities are actually fighting against the will of the President.

The emergence of the environmental movement as a powerful new force in public land management is an important factor in disturbing the political equilibrium (Nelson \& Fairfax, 1995). The most popular issue that is frequently raised by groups whose lives are deeply dependent on their voices on environmental issues, generally environmental NGOs, is deforestation. The issue of deforestation inevitably arises when there are major flood events that do not occur every year. Often their views seem too naive, or they deliberately don't be curious to know the real problem, that reducing forest area automatically causes deforestation. They have turned a blind eye to the fact that 35.5 million ha of land claimed as forest areas have long been non-forested. With the average income level of the Indonesian people, which is still around USD4,000 per capita annually, the environment is still a luxury item for most Indonesians. Those people are still struggling to meet their basic needs, namely adequate food in both quantity and quality. Meanwhile, the groups that speak out so much about environmental issues are generally groups that are already established economically, so that what actually happens is nothing other than environmental hypocrisy and bourgeoisie. Perhaps, the environmental issue is just an instrument to protect economic interest rather than to protect the environment itself.

It is crucial to describe luxury goods in bit detail to avoid confusion. In economics, a luxury item is a good for which demand increases more than proportionally as income rises. In other words, income elasticity of demand for luxury goods is greater than one. Verbally, as people become wealthier, they will purchase proportionally more luxury goods. On the contrary, that should there be a decline in income, its demand will drop more than proportionately. In general, luxury items are non-essentials that are typically high-quality and serve as status symbols. Hence, for low-income groups of society, luxury goods have extremely low priority in budget allocation.

The dense forest covering the largest part of Indonesia's land at the start of the New Order Regime was probably a trap and a curse for the Indonesian people. In the early days of economic development carried out by the New Order Regime, forests were a quick source of cash. Besides that, the natural forest is biologically a renewable resource, which easily leads people to believe that exploitation of natural forests can be carried out in a sustainable manner. In fact, the exploitation of natural forest that meets all applicable regulations is not financially profitable, so it is impossible to sustain consequently (van Gardingen et al., 2003; Soedomo, 2017). Both of these circumstances encourage forestry authorities to believe that forestry can be relied on in national economic development. In fact, there is no evidence that people whose lives depend entirely on forests can live in prosperity. Furthermore, empirical evidence also shows that the poorest people are generally those who live in or around forests (Sunderlin et al., 2007). This phenomenon has not changed until recently.

The significance of natural forests in supporting national development has diminished from time to time. Between the 1970 s and the mid-1990s, timber production from natural forests increased. But since that time until today, timber production from natural forests has continued to decline. If the number of companies, concession area and $\log$ production in 1990, respectively 556 units, 58.9 million ha, and 25.3 million $\mathrm{m}^{3}$, were normalized to one, the declining trend of the three figures can be seen (Figure 1). It appears that the number of companies receiving natural forest concessions in 2017 was only about half of the number of companies receiving natural forest concessions in 1990. Meanwhile, the log production from natural forest in 2017

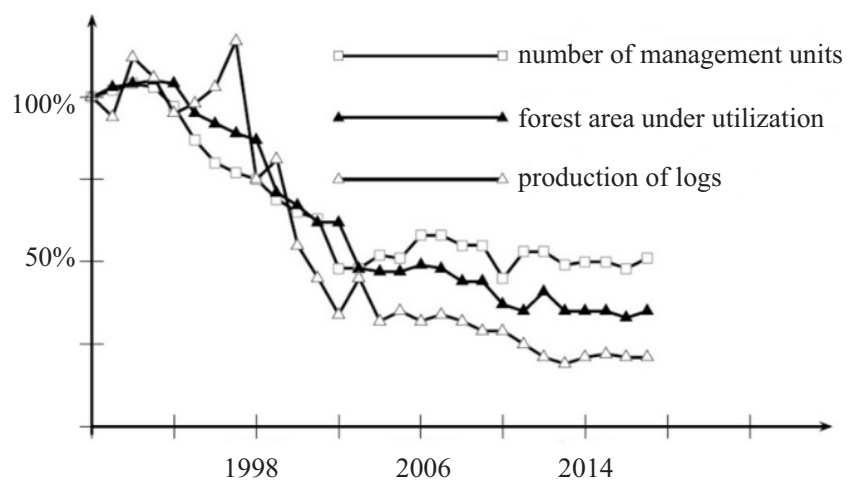

Figure 1 Trends of natural forest utilization since 1990.

\footnotetext{
${ }^{3}$ A state-owned company operating in Java Island
} 
was less than a quarter of the log production from natural forest in 1990. Indeed, not all companies that have obtained natural forest concessions are still actively running their business; some of them are no longer active and even intent to leave the natural forest exploitation industry, but the government does not allow it. It is understandable why the government does not allow natural forest concession companies to close down since it makes forest authorities look awful.

Meanwhile, the development of industrial forest plantations (HTI), which are expected to replace the role of natural forests, is far below expectations. The area of HTI that has received permits reached 11.2 million ha in 2017 , but how much HTI has been built and can be found in the field is still unclear. The available data only states the planted area per year, while data on how much HTI is cut each year is not available. Given that the largest part of the planted HTI are intended to produce pulpwood, the cutting cycle used is likely around six years. Therefore, it can be ascertained that part of the planted HTI has been felled. The Indonesian Forest Business Association (APHI) stated that in 20174.9 million ha had been built. But by using the data in Table 6 and the sixyear cycle, it is possible that the area of HTI that has been developed and can be found in the field is only 2.2 million ha. Pirard et al. (2016) estimated that in 2014 the HTI that has been developed was 2.25 million ha. Moreover, with a strongly severe wood supply, the price of wood is less attractive for investment. The situation will worsen if the supply of wood is abundant due to the success of plantation development.

The curse of natural forests is apparently contagious, and all land-based sectors are affected. The abundance of natural forest resources in the past influenced political decisions at that time, especially regarding land tenure by a sector, which has continued to the present day. In fact, these political decisions affect the space for other sectors to move in the following days. The abundance of natural resources does not influence the political system as presented by Collier (2010), but it certainly influences momentary political decisions which turn out to be difficult to change even when the natural forest is no longer there. Moreover, some of the major targets of lndonesia's Agrarian and Land Reform were undoubtedly political in nature, such as: attaching a "social function" to land ownership; giving soil to its tillers; and the eradication of excessive landownership to revise the landlord-tenant relationship in favor of the latter (Tjondroegoro, 1972).

Spatial plan and agrarian structure are the very foundation for agriculture development in particular and economic development in general. Unfortunately, this very critical foundation has never been established since the enactment date of Act 5 of 1960 regarding the UUPA. This Act replaced the Netherlands Indies agrarian legislation of 1870 (Utrecht, 1969). Although the agrarian reform has been an unsettled issue since the colonial era, I limit myself to the efforts of the agrarian reform from the issuance date of the UUPA until 2019. For historical events prior to the issuance of the UUPA, Lucas (1992) provides nice descriptions. The main question is why the agrarian reform as a vital foundation for agricultural development has not settled yet until today, whereas we do know that the agrarian issues become more complicated and much harder to solve over time unless the human is able to create a magical technology that can produce anything from nothing. In that way, we do not need lands anymore to make agricultural products vital for our survival.

Land governance in Indonesia is implemented in reverse, but this has rarely been paid attention to, let alone corrected. The provincial spatial plan needs approval, named a harmonization process (paduserasi), from the Forestry Authority prior to being legalized by the Provincial House of Representative through a Regional Regulation. According to the Forestry Act, the forestry authority must consult the spatial plan before establishing a forest area. In addition, a forestry ministerial decree can rule out a Regional Regulation, whereas a ministerial decree is not included in the hierarchy of rule and regulation in Indonesia. Moreover, when the collision results in disputes that potentially enter judiciary authority, the non-forestry authority usually chooses to avoid that path. It is not because his or her position is weaker before the law, but he or she avoids the cumbersome, expensive, and uncertain process.

Impacts of the TGHK establishment have been very severely devastating. Even though the TGHK is temporarily indicative, the forestry authority has treated it as sacredly permanent land allocation in Indonesia. TGHK is an unnecessary constraint for a regional spatial planning that seeks to optimize land use; spatial planning must be adjusted to TGHK through a process known as cohortation. In fact, the law clearly mandates that the designation of forest areas must refer to regional spatial planning. An optimization result with fewer constraints is never worse than an optimization result with more constraints. This misguided practise of statehood has been going on for a long time, even today, and no one knows when it will end. Another impact is the local community's rights to the land they cultivate. Figure 2 shows how this happens. Initially, the land cultivated by the local community and land that was claimed as forest area did not yet have legal boundaries as shown in node A; land designated as a candidate for the forest area has an inner legal boundary as well as an outer legal boundary. How to reach node $\mathrm{D}$ if there is a budget constraint, for example? Which of nodes $\mathrm{B}$ and $\mathrm{C}$ should be chosen? So far, the forestry authority has chosen node $\mathrm{B}$ to go to node $\mathrm{D}$. As a result, the land cultivated by the local community seems to be part of a

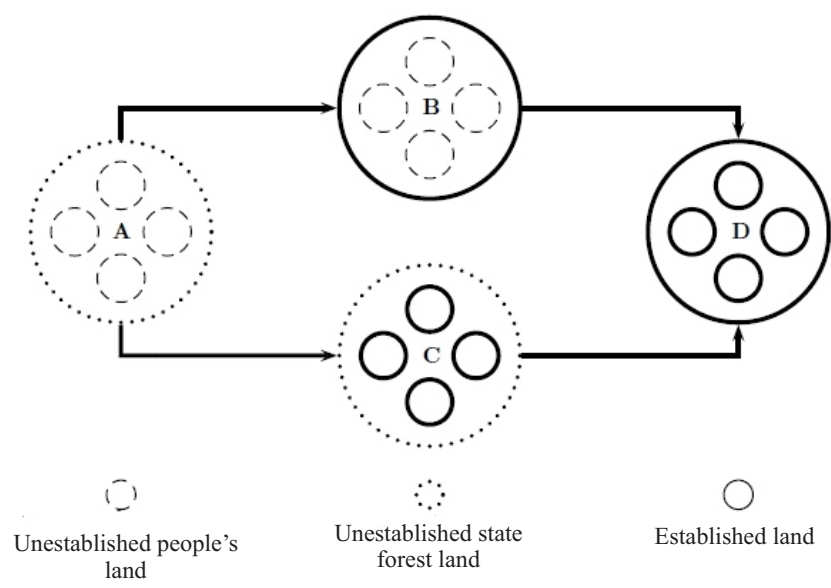

Figure 2 Effects of different routes of state forest area establishment. 
forest area, whereas the community cultivated lands have been trapped within the boundary of an area claimed as forest area due to the attitude of the forestry authorities which emphasizes power rather than the people's welfare. Furthermore, there is uncertainty over the communities' cultivated lands and this situation has been going on for decades without any sign of resolution in the near future.

Especially for the local community, unfinished claim over forest areas creates the uncertainties of land legality status, because the establishment of forest areas has never been completed properly. Numerous problems follow, such as:

- The lack of clarity on the status of land opens up opportunities for those without formal title to contest ownership (Bedner, 2016). It discourages long term investments in general. In short, strengthening land rights will potentially, not to say definitely, encourage participation among local communities in peatland restoration when the land is not claimed as state forest land and the participation improves their livelihood. A positive relationship between land tenure security and productivity has been ob- served (Feder \& Onchan, 1987; Besley, 1995; Nelson et al., 2001; Dekker, 2005; Deininger \& Jin, 2006). A person will better care for the land, work intensively, increase capital investment, and be a good steward environmentally. However, evidence that between land tenure and land productivity is unrelated also exists (Tucker, 1999; Fenske, 2011).

- Uncertainly of land legal status also creates a device for separating individuals according to their willingness to take a risk. The claimed forest areas are risky lands to invest. The ones with the higher willingness to take a risk might invest in the risky land, but those with the lower willingness to take a risk tend to avoid the lands. Briefly, the uncertainty of land legality status is, in essence, an indirect discrimination device. As a result, an inequality of land control increases favoring those who have a higher willingness to take a risk. Who are they? Some research shows that people who have higher wealth or income tend to be more tolerant of risk (Blume \& Friend, 1975; Cohn et al., 1975; Riley Jr \& Chow, 1992; Grable \& Lytton, 1999; Hallahan et al., 2003). This process ultimately results in inequality of land tenure in rural areas.

- Hampering asset capitalization. The status of a "forest area" is like a dead card or dead capital (De Soto, 2000). Poor peasants are not only landless, but they also do not have the capital to cultivate the land they obtain from the government. Land with unclear legality cannot be capitalized to obtain capital loans. In this context, cultivated land received by farmers from social forestry programs cannot be capitalized to obtain capital. Therefore, farmers participating in the social forestry program will still have difficulties in developing their business. To make matters worse, land use in forest areas has to follow a lot of unnecessary regulations which ultimately hinder achieving efficient use. Development with a top-down approach has been proven to have failed to provide prosperity (Easterly, 2014).

- The social impact of unclear land status is also profound.
Social services, such as education and health services are hampered for local governments do not have courage to allocate budgets to build education and health facilities for people whose land they live in is claimed as forest areas. Such budget allocations can be prosecuted by law with criminal charges. There is another case where a regent was unable to build a drainage channel to prevent flood inundation of his residents' settlements since the drainage channel had to pass through an area claimed to be part of a national park even though the area had long been a developing area.

These various consequences in turn lead to inefficient land use. Finally, a successful land reform allows for the transition of a society from an agriculture-based state of poverty to a human capital-based developed economy (Gersbach \& Siemers, 2010). In addition, land policies are of fundamental importance to sustainable growth, good governance, and the well-being of and the economic opportunities open to rural and urban dwellersparticularly poor people (Deinincer, 2007).

\section{Conclusion}

By setting aside protection and conservation forests, the forestry sector controls half of the cultivable area and the remaining half is used by various sectors. The productivity of land use by the forestry sector is much lower than the productivity of land use by other sectors. The population density in areas controlled by the forestry sector is generally much lower than the population density in other areas. Government control over areas controlled by the forestry sector is generally stronger than government control over other areas. Thus, if agrarian reform is to be carried out seriously and substantially, the forest area must be the priority object. Forestry regulations basically also hinder businesses in the forestry sector itself. The status of forest areas becomes a hiding place for forestry authorities to use their power without competition. Therefore, in order for this unproductive power to be exposed to competition, the status of production forest areas needs to be removed. Uses of the entire cultivable area should be contested for all possible uses. However, conservation forest areas and protected forest areas must be guarded and respected together. Forestry authorities are directed to manage forests, not to manage forest areas.

\section{References}

Atkins, F. (1988). Land reform: A failure of neoclassical theorization? World Development, 16, 935-946. https://doi.org/10.1016/0305-750x(88)90025-3

Bedner, A. (2016). Indonesian land law: Integration at last? And for whom? In J. F. McCarthy, \& K. Robinson (Eds.), Land and development in Indonesia (pp. 63-88). Singapore: ISEAS Publishing.

Besley, T. (1995). Property rights and investment incentives: Theory and evidence from Ghana. The Journal of Political Economy, 103(5), 903-937. http://www.jstor. org/stable/2138750 
Blume, M. E., \& Friend, I. (1975). The asset structure of individual portfolios and some implications for utility functions. The Journal of Finance, 30(2), 585-603. https://doi.org/10.1111/j.1540-6261.1975.tb01833.x

Cohn, R. A., Lewellen, W. G., Lease, R. C., \& Schlarbau, G. G. (1975). Individual investor risk aversion and investment portfolio composition. The Journal of Finance, 30(2), 605-620. https://doi.org/10.1111/j.15406261.1975.tb01834.x

Collier, P. (2010). The political economy of natural resources. Social Research, 77(4), 1105-1132. https://doi.org/ 10.2307/23347121

De Soto, H. (2000). The mystery of capital: Why capitalism triumphs in the west and fails everywhere else. New York: Basic Books.

Deinincer, K. (2007). Land policies for growth and poverty reduction. Oxford: The World Bank and Oxford University Press.

Deininger, K., \& Jin, S. (2006). Tenure security and landrelated investment: Evidence from Ethiopia. European Economic Review, 50, 1245-1277. https://doi.org/ 10.1016/j.euroecorev.2005.02.001

Dekker, H. A. (2005). In pursuit of land tenure security. Amsterdam: Pallas Publication.

Easterly, W. (2014). The tyranny of experts: Economists, dictators, and the forgotten rights of the poor. New York: Basic Books.

Feder, G., \& Onchan, T. (1987). Land ownership security and farm investment in Thailand. American Journal of Agricultural Economics, 69(2), 311-320. https://doi.org/ $10.2307 / 1242281$

Fenske, J. (2011). Land tenure and investment incentives: Evidence from West Africa. Journal of Development Economics, 95(2), 137-156. https://doi.org/10.2139/ ssrn. 1358631

Fox, J., Fujita, Y., Ngidang, D., Peluso, N., Potter, L., Sakuntaladewi, N., ..., \& Thomas, D. (2009). Policies, political-economy, and swidden in Southeast Asia. Human Ecology, 37(3), 305-322. https://doi.org/ $10.1007 / \mathrm{s} 10745-009-9240-7$

Gersbach, H. \& Siemers, L. H. (2010). Land reforms and economic development. Macroeconomic Dynamics, 14, 527-547.https://doi.org/10.1017/S136510050909049X

Grable, J. \& Lytton, R. H. (1999). Financial risk tolerance revisited: The development of a risk assessment instrument. Financial Services Review, 8(3), 163-181. https://doi.org/10.1016/S1057-0810(99)00041-4

Haar, C. (1976). A program for land registration and land transfer in Indonesia. Ekistics, 41(244), 155-157.
Hallahan, T., Faff, R., \& McKenzie, M. (2003). An exploratory investigation of the relation between risk tolerance scores and demographic characteristics. Journal of Multinational Financial Management, 13(45), 483-502. https://doi.org/10.1016/S1042-444X (03)00022-7

Henley, D. (2008). Natural resource management: Historical lessons from Indonesia. Human Ecology, 36(2), 273-290. https://doi.org/10.1007/s10745-007-9137-2

Holdena, S.T., Otsuka, K., \& Deininger, K. (2013). Land tenure reform in Asia and Africa: Assessing impacts on poverty and natural resource management. United Kingdom: Palgrave Macmillan.

Kahneman, D. \& Tversky, A. (1984). Choices, values and frames. American Psychologist, 39(4), 341-350. https://doi.org/10.1037/0003-066X.39.4.341

Lipton, M. (2009). Land reform in developing countries: Property rights and property wrongs (Reprint Ed.). Routledge Priorities in Development Economics.

Lucas, A. (1992). Land disputes in Indonesia: Some current perspectives. Indonesia, 53, 79-92. https://doi.org/ $10.2307 / 3351117$

Lucas, A. \& Warren, C. (2013). The land, the law, and the people. In A. Lucas, \& C. Warren (Eds.), Land for the people: The state and agrarian conflict in Indonesia (Chapter 1,pp. 1-39). Ohio University Press.

MacAndrews, C. (1978). Transmigration in Indonesia: Prospects and problems. Asian Survey, 18(5), 458-472. https://doi.org/10.2307/2643460

McCarthy, J. F. \& Robinson, K. (2016). Land, economic development, social justice and environmental management in Indonesia: The search for the people's sovereignty. In J. F. McCarthy, \& K. Robinson (Eds.), Land and development in Indonesia (pp. 1-34). Singapore: ISEAS Publishing.

Nelson, G. C., Harris, V., \& Stone, S. W. (2001). Deforestation, land use, and property rights: Empirical evidence from Dari'en, Panama. Land Economics, 77(2), 187-205.https://doi.org/10.2307/3147089

Nelson, R. H. \& Fairfax, S. K. (1995). Public lands and private rights: The failure of scientific management. Rowman \& Littlefield.

Pirard, R., Petit, H., Baral, H., \& Achdiawan, R. (2016). Dampak hutan tanaman industri di Indonesia: Analisis persepsi masyarakat desa di Sumatera, Jawa dan Kalimantan. Technical report. Center for International Forestry Research (CIFOR). https://doi.org/10.17528/ cifor/006137

Riley Jr. W. B. \& Chow, K. V. (1992). Asset allocation and individual risk aversion. Financial Analysts Journal, 
48(6), 32-37.https://doi.org/10.2469/faj.v48.n6.32

Samuelson, W. \& Zeckhauser, R. (1988). Status quo bias in decision making. Journal of Risk and Uncertainty, 1, 7-59. https://doi.org/10.1007/BF00055564

Soedomo, S. (2017). Failure of forestry political economy of Indonesia. Jurnal Manajemen Hutan Tropika, 23(2), 111-118.

Sunderlin, W. D., Dewi, S., \& Puntodewo, A. (2007). Poverty and forests: Multi-country analysis of spatial association. Center for International Forestry Research (CIFOR). https://doi.org/10.17528/cifor/002294

Tjondroegoro, S. M. (1972). Land reform or land settlement: Shifts in Indonesia's land policy, 1960-1970. University of Wisconsin.
Tucker, C. M. (1999). Private versus common property forests: Forest conditions and tenure in a Honduran community. Human Ecology, 27(2), 201-230. https://doi.org/10.1023/A:1018721826964

Utrecht, E. (1969). Land reform in Indonesia. Bulletin of Indonesian Economic Studies, 5(3), 71-88. https://doi.org/10.1080/00074916912331331482

van Gardingen, P., McLeish, M., Phillips, P., Fadilah, D., Tyrie, G., \& Yasman, I. (2003). Financial and ecological analysis of management options for logged-over dipterocarp forests in Indonesian Borneo. Forest Ecology and Management, 183(1-3), 1-29. https://doi.org/ 10.1016/S0378-1127(03)00097-5

Walinsky, L. (1977). Agrarian reform as unfinished business: The selected papers of Wolf Ladejinsky. New York: Oxford University Press. 